\title{
Application of fibre-FISH (fluorescence in situ hybridization) to filamentous fungi: visualization of the rRNA gene cluster of the ascomycete Cochliobolus heterostrophus
}

\author{
Dai Tsuchiya and Masatoki Taga
}

Department of Biology, Faculty of Science, Okayama University, Tsushima-naka, Okayama 700-8530, Japan
Author for correspondence: Masatoki Taga. Tel: +81 86251 8501. Fax: +81 862517876. e-mail:mtaga@cc.okayama-u.ac.jp

\begin{abstract}
Fibre-FISH (fluorescence in situ hybridization) has not been used in filamentous fungi before to the authors' knowledge. In this study, this technique was applied to a filamentous ascomycete, Cochliobolus heterostrophus, to visualize the organization of the rRNA gene clusters (rDNA). Using protoplasts embedded in agarose, DNA fibres were released from interphase nuclei and extended on a glass slide. Four kinds of probes (0.5-9.0 kb in size) that correspond to specific regions in the repeat unit of rDNA were hybridized singly or in combination to the DNA fibres, and the hybridization was detected with fluorescein- and/or rhodamine-conjugated antibodies after one round of signal amplification. The alternating arrangement of 185 and 285 rRNA genes as well as the tandem repetitive nature of the repeat units were clearly visualized by this single- or two-colour fibre-FISH. With a probe targeting the 5.85 or 185 rRNA gene, a region spanning over $800 \mathrm{~kb}$ could be visualized in a single fibre, allowing estimation of both the copy number of the repeat unit in rDNA and the stretching degree of the DNA fibre. It was shown that $C$.

heterostrophus has more than 90 copies of the repeat unit in its rDNA and the stretching degree was similar to the value based on the Watson-Crick model. Visualization of individual genes on an extended DNA fibre was accomplished in filamentous fungi by this study.
\end{abstract}

Keywords: ascomycete, chromatin, nucleolus, rDNA, ribosome

\section{INTRODUCTION}

Highly sensitive fluorescence in situ hybridization (FISH) has recently been developed (Heng et al., 1992; Wiegant et al., 1992; Parra \& Windle, 1993; Heiskanen et al., 1994). This technique is called fibreFISH because extended DNA fibres released from lysed nuclei are used as specimens for hybridization instead of nuclei or chromosomes as for conventional FISH. FibreFISH can distinguish two probes separated by $1 \mathrm{~kb}$ on a DNA fibre (Heng \& Tsui, 1998), and because of this resolution, has been used in mammals and plants for physical mapping (Parra \& Windle, 1993; Heiskanen et al., 1995; Raap et al., 1996; Jackson et al., 1998), detection of genomic rearrangement (Parra \& Windle, 1993; Heiskanen et al., 1995), direct visualization of DNA replication (Rosenberg et al., 1995), positional

Abbreviation: $\mathrm{FISH}$, fluorescence in situ hybridization. cloning (Courseaux et al., 1996; Leppanen et al., 1996), analysis of gene organization (Fransz et al., 1996; Ersfeld et al., 1998; Liu et al., 1998), and so on.

In spite of the proven usefulness of fibre-FISH in higher eukaryotes, no report using this technique has been published so far for fungi. Considering the extreme smallness of their chromosomes and nuclei compared with those of higher organisms, it is not surprising that application of conventional FISH to the metaphase chromosomes or interphase nuclei has been very limited in this group of organisms (Taga \& Murata, 1994; Taga et al., 1999). Regarding fibre-FISH, however, there seems to be no innate hindrance to its use in fungi. Once DNA fibres are properly prepared, FISH techniques should be applicable to fungal DNA fibres without difficulty, as in other organisms.

In this study, we aimed to establish the fibre-FISH technique for filamentous fungi using an ascomy- 
cetous corn pathogen, Cochliobolus heterostrophus (Drechsler) Drechsler [anamorph, Bipolaris maydis (Nishikado and Miyake) Shoemaker]. This fungus serves as a model fungal pathogen in plant pathology with which extensive molecular genetic studies have been conducted. As the target DNA sequences, we chose the rRNA gene cluster, or rDNA, because relatively easy detection of this region, owing to its repetitive nature and occupation of a large part of a nucleolar chromosome (M. Taga, D. Tsuchiya \& M. Murata, unpublished results), was thought to make it suitable for screening and establishing experimental conditions for fibre-FISH techniques in this fungus.

In this study, procedures for preparing DNA fibres for FISH were established in C. heterostrophus. With these fibres, the in situ organization of rDNA in terms of the arrangement of rRNA genes in the cluster was visually revealed by single- or two-colour fibre-FISH. Data for the number of repeat units in rDNA and the stretching degree of the DNA fibre were also obtained. To our knowledge, this is the first report of visualization of individual genes on an extended DNA fibre in fungi.

\section{METHODS}

Preparation of protoplast-embedded agarose block. Protoplasts from hyphal cells of $C$. heterostrophus strain B30.A3.R.45 (a gift from C. R. Bronson, Department of Plant Pathology, Iowa State University, Ames, IA, USA) were embedded in low melting agarose (hereinafter called protoplast-agarose block), and used as the source of nuclei from which DNA fibres were to be released. The methods for protoplasting and embedding of cells were the same as those used for PFGE. Briefly, conidia harvested from 1-week-old cultures were incubated in liquid complete medium (Leach et al., 1982) at a concentration of $1 \times 10^{6} \mathrm{ml}^{-1}$, and allowed to germinate on a reciprocal shaker at 110 strokes $\min ^{-1}$ for $12-15 \mathrm{~h}$ at $27^{\circ} \mathrm{C}$. The germlings were vacuum-filtered on filter paper (Whatman no. 4), washed with $0.7 \mathrm{M} \mathrm{NaCl}$, then suspended in 6-10 ml filter-sterilized enzyme solution [Novozym 234 (Novo Biolabs) $2 \mathrm{mg}$; Kitalase (Wako Pure Chemical) $3 \mathrm{mg}$; $\beta$-glucuronidase (type HA-4, Sigma) $3 \mathrm{mg} \mathrm{ml}^{-1}$ of $0.7 \mathrm{M} \mathrm{NaCl}$. After $2-4 \mathrm{~h}$ incubation at $30^{\circ} \mathrm{C}$ on a reciprocal shaker $\left(65-75\right.$ strokes $\left.\mathrm{min}^{-1}\right)$, protoplasts were filtered through four layers of Kimwipe (Jujo Kimberly), collected by centrifugation at $550 \mathrm{~g}$ for $10 \mathrm{~min}$, and the pellet was washed twice with $0.7 \mathrm{M} \mathrm{NaCl}$ by centrifugation. The final protoplast pellet was suspended in SE (1 M sorbitol, $50 \mathrm{mM}$ EDTA, pH 8.0$)$, embedded in $0.5 \%(\mathrm{w} / \mathrm{v})$ low melting agarose (Bio-Rad) in SE at a final concentration of approximately $1 \times 10^{8}$ protoplasts $\mathrm{ml}^{-1}$, and then incubated in NDS (0.5 M EDTA; $10 \mathrm{mM}$ Tris/ $\mathrm{HCl}, \mathrm{pH} 8.0 ; 1 \%$, w/v, sodium lauroyl sarcosinate] for $14 \mathrm{~h}$ at $37^{\circ} \mathrm{C}$ to lyse cells. After being rinsed three times in $50 \mathrm{mM}$ EDTA ( $\mathrm{pH} \mathrm{8.0)} \mathrm{for} 30$ min each at $37{ }^{\circ} \mathrm{C}$, samples were stored in this solution at $4{ }^{\circ} \mathrm{C}$ until they were used.

Preparation of DNA fibres. Glass slides were coated with polyL-lysine (Sigma) by soaking for $5 \mathrm{~min}$ and dried at room temperature overnight. A tiny protoplast-agarose block (approx. $20 \mu \mathrm{l}$ ) was placed on a slide and mounted with $40 \mu \mathrm{l}$ sterile water. The slide was placed on a heat block at $85^{\circ} \mathrm{C}$ for $20-30 \mathrm{~s}$ to melt the agarose. The liquified agarose drop was mechanically extended with a coverslip as described by Heiskanen et al. (1994) and air-dried. The slides were treated

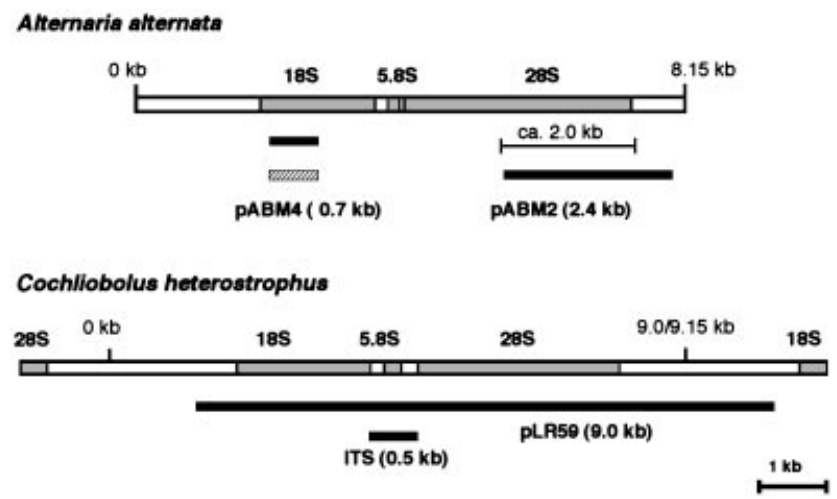

Fig. 1. Probes used for FISH and their target sites in rDNA. $\mathrm{pABM} 2$ and $\mathrm{pABM} 4$ are from Alternaria alternata. Probes represented as black and hatched bars were labelled with biotin and digoxigenin, respectively. Hybridization of these probes with target sites was visualized with fluoresceinconjugated (for biotinylated probes) or rhodamine-conjugated (for digoxigenin-labelled probes) secondary antibodies. Physical maps of the repeat unit of rDNA of $C$. heterostrophus and $A$. alternata are based on Garber et al. (1988) and Tsuge et al. (1989), respectively.

with $100 \mu \mathrm{g}$ RNase A ml ${ }^{-1}$ in $2 \times$ SSC $(1 \times$ SSC: $0 \cdot 15 \mathrm{M} \mathrm{NaCl}$, $0.015 \mathrm{M}$ sodium citrate) for $45 \mathrm{~min}$ at $37^{\circ} \mathrm{C}$, dehydrated through an ethanol series (70-80-99\%), and air-dried.

DNA probes. Four probes, each corresponding to a specific part of the repeat unit of rDNA, were used (Fig. 1). pABM2 and pABM4 are heterologous probes from the filamentous imperfect fungus Alternaria alternata, each of which contains $\mathrm{XbaI}$ fragments of the rDNA repeat unit of this fungus in Bluescribe M13 (Tsuge et al., 1989). pLR59 contains a $9 \mathrm{~kb}$ PvuII fragment corresponding to the whole repeat unit of $C$. heterostrophus in pBR322 (Garber et al., 1988). These three plasmid DNAs were isolated as described by Maniatis et al. (1982). ITS, which covers the whole region of the internal transcribed spacers and the 5.8S rRNA gene, was amplified by PCR with universal primers ITS1 and ITS4 (White et al., 1990) using total genomic DNA of B30.A3.R.45 as template. The PCR reaction mixture contained approximately $100 \mathrm{ng}$ template DNA, $200 \mu \mathrm{M}$ each of dNTPs, $1.5 \mathrm{mM} \mathrm{MgCl}_{2}$, and $1.25 \mathrm{U} \mathrm{Taq}$ polymerase (Toyobo) in a $50 \mu \mathrm{l}$ reaction volume. The thermal conditions were $10 \mathrm{~min}$ at $94^{\circ} \mathrm{C}$, followed by 35 cycles of $30 \mathrm{~s}$ at $94^{\circ} \mathrm{C}, 30 \mathrm{~s}$ at $55^{\circ} \mathrm{C}$, and $1 \mathrm{~min}$ at $72^{\circ} \mathrm{C}$, then final extension for $10 \mathrm{~min}$ at $72^{\circ} \mathrm{C}$. After completion of the reaction, an aliquot of the mixture was directly used as a template for PCR labelling.

Probe labelling. For pABM2 and pLR59, the whole plasmid (vector plus insert) was labelled with biotin-14-dATP by nick translation using the BioNick Labelling System (Gibco-BRL). For pABM4, the insert was excised from the plasmid, and labelled with digoxigenin-11-dUTP by nick translation using the Nick Translation Kit (Boehringer Mannheim). ITS was biotin-labelled by PCR with the primers ITS1 and ITS4 under the following conditions. The reaction mixture included $1 \mu \mathrm{l}$ of the amplified product of the first PCR, $160 \mu \mathrm{M}$ biotin-16dUTP (Boehringer Mannheim), $80 \mu \mathrm{M}$ dTTP, $200 \mu \mathrm{M}$ each of the other dNTPs, $10 \mathrm{mM}$ Tris $/ \mathrm{HCl}(\mathrm{pH} \mathrm{8} 3), 50 \mathrm{mM} \mathrm{KCl}$, $1.5 \mathrm{mM} \mathrm{MgCl}_{2}$ and $1.25 \mathrm{U} \mathrm{Taq}$ polymerase (Toyobo) in a $50 \mu \mathrm{l}$ reaction volume. The thermal conditions were $5 \mathrm{~min}$ at $94^{\circ} \mathrm{C}$, followed by 25 cycles of $1 \mathrm{~min}$ at $94^{\circ} \mathrm{C}, 1 \mathrm{~min}$ at $62^{\circ} \mathrm{C}$, $3 \mathrm{~min}$ at $72{ }^{\circ} \mathrm{C}$, and a final extension of $10 \mathrm{~min}$ at $72^{\circ} \mathrm{C}$. The 
amplified DNA was subsequently purified by ethanol precipitation to remove free oligonucleotides and unincorporated dNTPs.

In situ hybridization. Hybridization mixture $(50 \%, \mathrm{v} / \mathrm{v}$, formamide; $10 \%, \mathrm{w} / \mathrm{v}$, dextran sulfate; $100 \mathrm{ng}$ sonicated salmon sperm DNA $\mu \mathrm{l}^{-1}$; and the proper amount of labelled probe DNA $/ 2 \times$ SSC) was applied to the specimen, covered with a coverslip $(18 \times 32 \mathrm{~mm})$, and sealed with rubber cement. The slide was heated for denaturation on a hot plate at $80^{\circ} \mathrm{C}$ for $5 \mathrm{~min}$, and incubated for hybridization at $37^{\circ} \mathrm{C}$ for 16-20 h. After hybridization, the coverslip was removed by floating it off in $2 \times$ SSC. Subsequently, the slide was washed once for $15 \mathrm{~min}$ in $50 \%$ formamide dissolved in $4 \times \mathrm{SSC}$ at $37^{\circ} \mathrm{C}$, twice for $8 \mathrm{~min}$ in $2 \times$ SSC, once in $4 \times$ SSC for 5 min, and then blocked with $1 \%$ Block Ace (Dainippon Pharmaceutical) $/ 4 \times$ SSC for $10 \mathrm{~min}$ at room temperature. Hybridization of biotin-labelled probes was detected with goat anti-biotin antibody (Vector Laboratories) followed by staining with fluorescein-conjugated rabbit anti-goat antibody (Boehringer Mannheim). Hybridization of digoxigeninlabelled probes was detected with mouse anti-digoxigenin (Boehringer Mannheim) followed by amplification with rhodamine-conjugated rabbit anti-mouse antibody (Chemicon International). All of the antibodies were diluted in $4 \times$ SSC containing $1 \%$ Block Ace. Incubations for detection and staining were $1 \mathrm{~h}$ each at $37^{\circ} \mathrm{C}$, followed by washing for $5 \mathrm{~min}$ in $4 \times$ SSC, for $5 \mathrm{~min}$ in $4 \times$ SSC containing $0 \cdot 1 \%$ Triton $\mathrm{X}-100$, and for $5 \mathrm{~min}$ in $4 \times$ SSC. Finally, the specimens were mounted with an antifading solution, Vectashield (Vector Laboratories).

Fluorescence microscopy. Observations were made with an epifluorescence microscope (Olympus BHS-RFC) equipped with an IB excitation filter cube (Olympus BH2-DMIB) for fluorescein, and triple band pass filter (Chroma) for twocolour FISH. Photographs were taken on 800 ASA/ISO colour print film (Fujicolor Super HG800). The colour images on the negatives were digitized with a film scanner (Coolscan II; Nikon), and processed by personal computer software Photoshop version 5.0 (Adobe).

\section{RESULTS AND DISCUSSION}

\section{Visualization of the rDNA region on DNA fibres}

Extended DNA fibres were easily prepared from protoplast-agarose blocks. The feasibility of FISH to the DNA fibres was first confirmed by using a plasmid probe, pLR59, whose insert encompasses an entire rDNA repeat unit (Fig. 2a). As expected, a long linear track consisting of consecutive signals was observed by this FISH, indicating that our procedures worked satisfactorily to visualize rDNA on the DNA fibre. At least 20-30 DNA fibres with such signals for rDNA were usually observed per slide. The protoplast-agarose blocks used in this study had been kept in a refrigerator for almost 2 years. Together with our experience of other fungi in which DNAs in protoplast-agarose blocks were mostly intact after at least 7-8 years' storage (D. Tsuchiya \& M. Taga, unpublished result), considerably long-term storage of the block may be possible for fibreFISH. Although proteinase $\mathrm{K}$ treatment was reported to be important for preparing DNA fibres of good quality (Heiskanen et al., 1995), our result suggests that such treatment is not essential, at least in filamentous fungi.

\section{Analyses of the copy number of a repeat unit and} the stretching degree of DNA fibres

Two probes, pABM4 and ITS, were used for hybridization to detect the $18 \mathrm{~S}$ and $5.8 \mathrm{~S}$ rRNA genes. With either probe, a long string of signals with similar signal intervals was observed [Fig. 2b, parts (i) and (ii)]. These results apparently showed the regularly repeated arrangement of the two genes in the rDNA. The observed number of signals on each DNA fibre, which should represent the copy number of a repeat unit, varied depending on the fibre. For the total of 110 DNA fibres counted for both probes, the number ranged from 37 to 92 , with a mean of 62 . More than two-thirds of the total counts fell between 50 and 80 . Considering that the smaller numbers in these counts were probably artefacts caused by several factors such as shearing of DNA fibres, fading out of signals, and poor hybridization, it seems to be reasonable to state that $C$. heterostrophus has at least 92 copies in a cluster. This estimation is compatible with the previous estimate of 130 copies by conventional Southern hybridization analysis for this fungus (Garber et al., 1988), the reliability of which, however, has never been examined. Since FISH is superior to Southern hybridization analysis in measuring copy number, a firm conclusion as to the number of repeats could be derived from future FISH analysis on the whole rDNA region.

As to the interval length between signals, there was no significant difference between the two FISH experiments; i.e. the mean lengths in the FISH with pABM4 and that with ITS were $3 \cdot 47 \pm 0 \cdot 11 \mu \mathrm{m}$ [observed number $(n)=256]$ and $3.35 \pm 0.09 \mu \mathrm{m}(n=221)$, respectively. Adopting $9 \cdot 0$ or $9 \cdot 15 \mathrm{~kb}$ as the size of the repeat unit of this fungus (Garber et al., 1988), the stretching degree of DNA fibres was calculated to be 2.64 (= $9 \cdot 0 / 3 \cdot 41) \mathrm{kb} \mathrm{\mu m}^{-1}$ (weighted mean length for both experiments) or $2.68(=9 \cdot 15 / 3.41) \mathrm{kb} \mathrm{\mu m}^{-1}$. These are in reasonable agreement with the extension of B-DNA of the Watson-Crick model $\left(2 \cdot 9 \mathrm{~kb} \mathrm{\mu m}^{-1}\right)$ as well as with the values obtained in other organisms, i.e. $2.77 \mathrm{~kb} \mathrm{\mu m}^{-1}$ for mammalian rDNA (Shiels et al., 1997) and $3.27 \mathrm{~kb} \mathrm{\mu m}^{-1}$ for plant rDNA (Fransz et al., 1996).

In addition, these experiments showed that preparation of DNA fibres exceeding $800 \mathrm{~kb}(9 \mathrm{~kb} \times 90$ copies $=$ $810 \mathrm{~kb}$ ) is possible in fungi. The upper limit of fibre length in fibre-FISH had been claimed to be approximately $500 \mathrm{~kb}$ in mammals (Heng \& Tsui, 1998; Heiskanen et al., 1996), whereas de Jong et al. (1999) indicated that long fibres up to $1 \mathrm{Mb}$ are obtainable in plants. Preparation of fibres $1 \mathrm{Mb}$ long may be possible irrespective of the kind of organism.

\section{Analysis of arrangement of $18 \mathrm{~S}$ and $28 \mathrm{~S}$ rRNA genes in rDNA}

Two-colour FISH was carried out to analyse the arrangement of $18 \mathrm{~S}$ and $28 \mathrm{~S}$ rRNA genes in the cluster. The biotinylated insert that was excised from pABM2 and the digoxigenin-labelled pABM4 were simultaneously hybridized to the same specimen, and the 
(a)

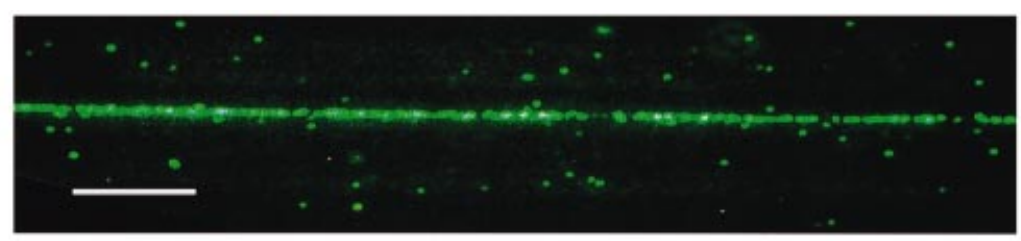

(b)
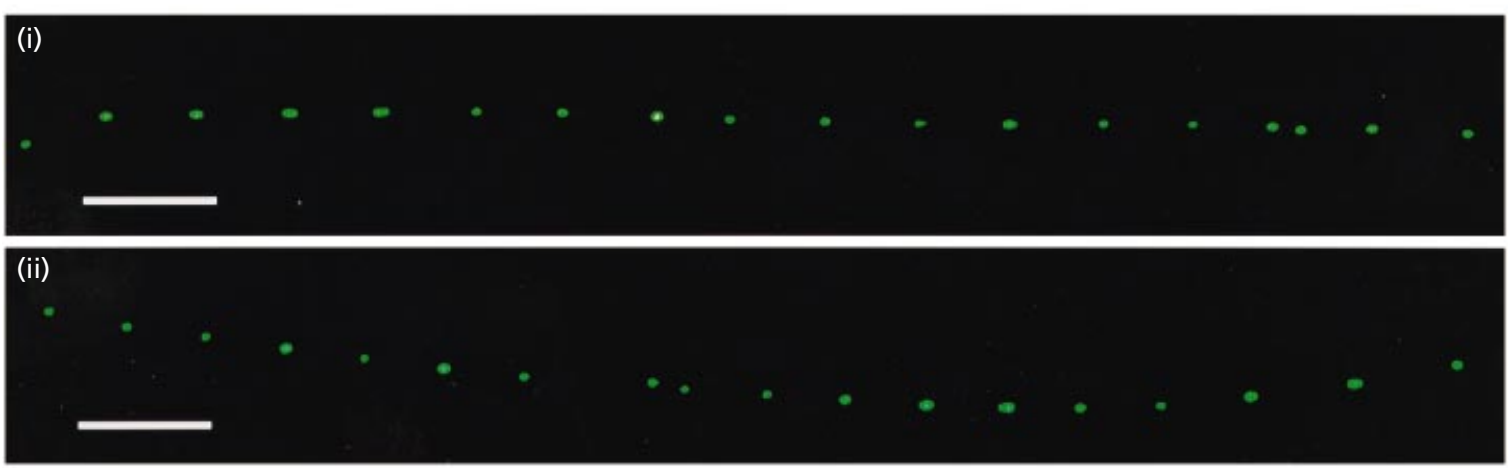

(c)

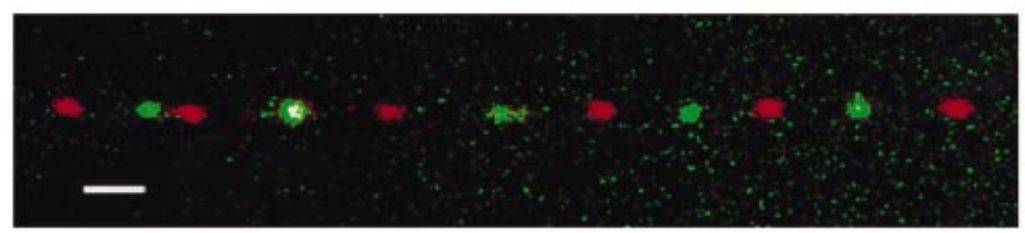

Fig. 2. (a) Fibre-FISH showing an rDNA region on a DNA fibre of $C$. heterostrophus. The biotinylated probe pLR59 that includes the entire rDNA repeat unit of the fungus was hybridized. Detection and fluorescence staining were done with fluorescein-conjugated antibody after one round of signal amplification. A long linear green track represents an rDNA region. Observation was made under IB excitation. Bar, $5 \mu \mathrm{m}$. (b) Fibre-FISH targeting a specific site in the rDNA repeat unit of $C$. heterostrophus. (i) Internal transcribed spacer region including the 5.8S rRNA gene detected with the $0.5 \mathrm{~kb}$ probe ITS; (ii) 18S rRNA gene detected with the $0.7 \mathrm{~kb}$ probe pABM4. Both probes were biotinylated and the hybridization was visualized as in part (a). Bar, $5 \mu \mathrm{m}$. (c) Two-colour fibre-FISH showing the alternating arrangement and tandem repeat of $18 \mathrm{~S}$ and $28 \mathrm{~S}$ rRNA genes in an rDNA cluster of $C$. heterostrophus. The two probes pABM2 and pABM4 targeting the $28 \mathrm{~S}$ and $18 \mathrm{~S}$ rRNA gene, respectively, were used. Red signals represent $18 \mathrm{~S}$ rRNA genes and green signals represent 285 rRNA genes. Observations were made with a triple band pass filter. Bar, $1 \mu \mathrm{m}$.

hybridization was detected with fluorescein- and rhodamine-conjugated secondary antibodies. As shown in Fig. 2(c), alternating green and red signals corresponding to the sites of $28 \mathrm{~S}$ and $18 \mathrm{~S}$ rRNA genes were observed. Using a rather simpler detection system in which biotinylated and digoxigenin-labelled probes were detected with avidin-FITC and rhodamineconjugated anti-digoxigenin antibodies, respectively, signals were hardly visible. The result of this FISH presents proof for the head-to-tail tandem repetition of the units in rDNA. The space between neighbouring green or red signals was roughly constant, the mean of which was $3 \cdot 89 \pm 0 \cdot 22 \mu \mathrm{m}(n=22)$. With this value, the stretching degree of the DNA fibre was calculated as above to be $2 \cdot 31$ or $2.35 \mathrm{~kb} \mathrm{\mu m}^{-1}$.

\section{Concluding remarks}

In this study, the organization of rDNA in terms of the arrangement of rRNA genes was visualized for the first time in fungi. Except for $5 \mathrm{~S}$ rDNA, as far as we know, there have been only two papers that have used fibreFISH for visualizing the array of rDNA repeats. In a plant, Fransz et al. (1996) revealed the tandem repeated array of $18 \mathrm{~S}$ and $28 \mathrm{~S}$ rRNA genes in Arabidopsis thaliana by two-colour FISH. In a mammal, the repeated arrangement of $18 \mathrm{~S}$ rRNA genes was shown by singlecolour FISH with a probe containing a partial region of the gene (Shiels et al., 1997). In contrast with the present study, counting of the copy number of repeat units was not performed in either paper. As to the FISH procedures used for the prepared DNA fibre, two rounds of signal amplification were done by Fransz et al. (1996), but a single round of amplification gave satisfactory results in the work of Shiels et al. (1997) and our work.

This study was done using an ordinary epifluorescence microscope equipped with a camera for $35 \mathrm{~mm}$ film. As claimed for other organisms (Wiegant et al., 1992; Zhong et al., 1998), instruments such as a cooled CCD 
camera are not essential for performing fibre-FISH in fungi as well. Therefore, studies similar to ours can be conducted in modestly equipped laboratories.

With the same procedures as described here, we have succeeded in visualizing $28 \mathrm{~S}$ rRNA genes in another filamentous ascomycete, Nectria haematococca (anamorph, Fusarium solani), as well as detecting a single copy gene, DEC1, which encodes decarboxylase in C. heterostrophus (D. Tsuchiya \& M. Taga, unpublished results). This indicates the versatility of our procedures in filamentous fungi. Thus the merits of fibre-FISH, such as higher mapping resolution and detection sensitivity, will be enjoyed in various aspects of genetic study for many fungi. The introduction of this method will especially accelerate high-resolution physical mapping of genomic clones and contribute to the elucidation of genome organization of fungi.

\section{ACKNOWLEDGEMENTS}

We thank T. Tsuge (Nagoya University) for providing plasmids pABM2 and pABM4, O.C. Yoder (Cornell University) for pLR59, and C. R. Bronson (Iowa State University) for C. heterostrophus strain B30.A3.R.45.

\section{REFERENCES}

Courseaux, A., Grosgeorge, J., Gaudray, P. \& 14 other authors (1996). Definition of the minimal MEN1 candidate area based on a 5-Mb integrated map of proximal 11q13. Genomics 37, 345-353.

Ersfeld, K., Asbeck, K. \& Gull, K. (1998). Direct visualisation of individual gene organisation in Trypanosoma brucei by highresolution in situ hybridisation. Chromosoma 107, 237-240.

Fransz, P. F., Alonso-Blanco, C., Liharska, T. B., Peeters, A. J. M., Zabel, P. \& de Jong, J. H. (1996). High-resolution physical mapping in Arabidopsis thaliana and tomato by fluorescence in situ hybridization to extended DNA fibers. Plant J 9, 421-430.

Garber, R. C., Turgeon, B. G., Selker, E. U. \& Yoder, O. C. (1988). Organization of ribosomal RNA genes in the fungus Cochliobolus heterostrophus. Curr Genet 14, 573-582.

Heiskanen, M., Karhu, R., Hellsten, E., Peltonen, L., Kallioniemi, O. P. \& Palotie, A. (1994). High resolution mapping using fluorescence in situ hybridization to extended DNA fibers prepared from agarose-embedded cells. Biotechniques 17, 928-934.

Heiskanen, M., Hellsten, E., Kallioniemi, O. P., Mäkelä, T. P., Alitalo, K., Peltonen, L. \& Palotie, A. (1995). Visual mapping by fiber-FISH. Genomics 30, 31-36.

Heiskanen, M., Kallioniemi, O. \& Palotie, A. (1996). Fiber-FISH: experiences and a refined protocol. Genet Anal Biomol Eng 12, 179-184.

Heng, H. H. Q. \& Tsui, L. C. (1998). High resolution free chromatin/DNA fiber fluorescent in situ hybridization. $J$ Chromatogr A 806, 219-229.

Heng, H. H. Q., Squire, J. \& Tsui, L. C. (1992). High resolution mapping of mammalian genes by in situ hybridization to free chromatin. Proc Natl Acad Sci U S A 89, 9509-9513.

Jackson, S. A., Wang, M. L., Goodman, H. M. \& Jiang, J. (1998).
Application of fiber-FISH in physical mapping of Arabidopsis thaliana. Genome 41, 566-572.

de Jong, J. H., Fransz, P. \& Zabel, P. (1999). High resolution FISH in plants - techniques and applications. Trends Plant Sci 4, 258-263.

Leach, J., Lang, B. R. \& Yoder, O. C. (1982). Methods for selection of mutants and in vitro culture of Cochliobolus heterostrophus. J Gen Microbiol 128, 1719-1729.

Leppanen, P., Isosomppi, J., Schleutker, J., Aulla, P. \& Peltonen, L. (1996). A physical map of the 6q14-q15 region harboring the locus for the lysosomal membrane sialic acid transport defect. Genomics 37, 62-67.

Liu, W. S., Soldatov, N. M., Gustavsson, I. \& Chowdhary, B. P. (1998). Fiber-FISH analysis of the 3 '-terminal region of the human L-type $\mathrm{Ca}^{2+}$ channel $\alpha_{1 \mathrm{c}}$ subunit gene. Hereditas 129, 169-175.

Maniatis, T., Fritsch, E. F. \& Sambrook, J. (1982). Molecular Cloning: a Laboratory Manual. Cold Spring Harbor, NY: Cold Spring Harbor Laboratory.

Parra, I. \& Windle, B. (1993). High resolution visual mapping of stretched DNA by fluorescent hybridization. Nat Genet 5, 17-21.

Raap, A. K., Florijn, R. J., Blonden, L. A. J., Wiegant, J., Vaandrager, J. W., Vrolijk, H., den Dunnen, J., Tanke, H. J. \& van Ommen, G. J. B. (1996). Fiber FISH as a DNA mapping tool. Methods 9, 67-73.

Rosenberg, C., Florijn, R. J., Van De Rijke, F. M., Blonden, L. A. J., Raap, A. K., van Omen, G. J. B. \& Den Dunnen, J. (1995). High resolution DNA fiber-FISH on yeast artificial chromosomes: direct visualization of DNA replication. Nat Genet 10, 477-479.

Shiels, C., Coutelle, C. \& Huxley, C. (1997). Analysis of ribosomal and alphoid repetitive DNA by fiber-FISH. Cytogenet Cell Genet 76, 20-22.

Taga, M. \& Murata, M. (1994). Visualization of mitotic chromosomes in filamentous fungi by fluorescence staining and fluorescence in situ hybridization. Chromosoma 103, 408-413.

Taga, M., Murata, M. \& VanEtten, H. D. (1999). Visualization of a conditionally dispensable chromosome in the filamentous ascomycete Nectria haematococca by fluorescence in situ hybridization. Fungal Genet Biol 26, 169-177.

Tsuge, T., Kobayashi, H. \& Nishimura, S. (1989). Organization of ribosomal RNA genes in Alternaria alternata Japanese pear pathotype, a host-selective AK-toxin-producing fungus. Curr Genet 16, 267-272.

White, T. J., Bruns, T., Lee, S. \& Taylor, J. (1990). Amplification and direct sequencing of fungal ribosomal RNA genes for phylogenetics. In PCR Protocols: a Guide to Methods and Applications, pp. 225-234. Edited by M. A. Innis, D. H. Gelfand, J. J. Sninsky \& T. J. White. San Diego, CA: Academic Press.

Wiegant, J., Kalle, W., Mullenders, L., Brookes, S., Hoovers, J. M. N., Dauwerse, J. G., van Omen, G. J. B. \& Raap, A. K. (1992). High-resolution in situ hybridization using DNA halo preparations. Hum Mol Genet 1, 587-591.

Zhong, X. B., Fransz, P. F., van Eden, J. W., Ramanna, M. S., van Kammen, A., Zabel, P. \& de Jong, J. H. (1998). FISH studies reveal the molecular and chromosomal organization of individual telomere domains in tomato. Plant J 13, 507-517.

Received 8 September 2000; revised 18 December 2000; accepted 15 January 2001. 